\title{
Pengembangan Media Pembelajaran Game PEKA Untuk Meningkatkan Hasil Belajar Kognitif Peserta Didik Pada Materi Pecahan
}

\author{
Alfa Reza Silvia Putri', Gamaliel Septian Airlanda² \\ 292016153@student.uksw.edu1, gamaliel.septian@uksw.edu² \\ Pendidikan Guru Sekolah Dasar, Fakultas Keguruan dan IImu Pendidikan, \\ Universitas Kristen Satya Wacana ${ }^{1,2}$
}

\begin{abstract}
Based on the results of observations, there are problems with elementary school students, namely not maximum learning outcomes in the mathematical fraction count operations material. The purpose of this research and development is to develop the PEKA game media (Mathematical Fraction) that can be used as a learning media for fractions to improve learning outcomes. The PEKA game media was created to facilitate the delivery of material and student's understanding of fractions. In this research and development, the writer uses the model developed by Borg \& Gall. The steps used in this research and development are (1) Research and development of initial information, (2) Planning, (3) Development of initial product drafts, (4) Initial trials, (5) Product revision. The results showed that the PEKA game media scored very well. The average score obtained from material experts is $84 \%$ with very good assessment criteria, and the average score obtained from media experts is $92 \%$ with very good assessment criteria.
\end{abstract}

Keywords: the PEKA game, fraction, learning outcomes

\begin{abstract}
Abstrak
Berdasarkan hasil observasi terdapat permasalahan pada peserta didik sekolah dasar yaitu kurang maksimalnya hasil belajar pada materi operasi hitung pecahan matematika. Tujuan penelitian dan pengembangan ini adalah untuk mengembangkan media game PEKA (Pecahan Matematika) yang dapat digunakan sebagai media pembelajaran pada materi pecahan untuk meningkatkan hasil belajar peserta didik. Media game PEKA dibuat untuk memudahkan penyampaian materi dan pemahaman peserta didik dalam materi pecahan. Dalam penelitian dan pengembangan ini penulis menggunakan model yang dikembangkan oleh Borg \& Gall. Langkah-langkah yang digunakan dalam penelitian dan pengembangan ini adalah: (1) Penelitian dan pengembangan informasi awal, (2) Perencanaan, (3) Pengembangan draf produk awal, (4) Uji coba awal, (5) Revisi produk. Berdasarkan hasil penelitian menunjukkan media game PEKA mendapat skor dengan kriteria sangat baik sehingga layak untuk digunakan sebagai media pembelajaran. Rata-rata yang diperoleh dari ahli materi adalah $84 \%$ dengan kriteria penilaian sangat baik dan rata-rata yang diperoleh dari ahli media adalah $92 \%$ dengan kriteria penilaian sangat baik.
\end{abstract}

Kata Kunci: game PEKA, pecahan, hasil belajar

\section{PENDAHULUAN}

Tercapainya tujuan pembelajaran dan proses pembelajaran yang baik, guru dapat menggunakan media pembelajaran agar pembelajaran lebih menyenangkan (Amir, 2014). Dengan menggunakan media pembelajaran peserta didik akan lebih mudah memahami konsep-konsep matematika yang abstrak menjadi konkrit dan peserta didik akan memiliki rasa ingin tahu dan tertarik untuk mendapatkan pengalaman baru. Hal ini mendorong pendidik untuk dapat melakukan usaha dalam pengembangan media pembelajaran yang sesuai dengan materi dan minat peserta didik di era perkembangan teknologi saat ini. Perkembangan teknologi saat ini dapat dimanfaatkan untuk 
memberikan inovasi dalam perkembangan media pembelajaran yang dapat membantu keberhasilan pembelajaran serta memenuhi tuntutan perkembangan zaman. Media pembelajaran yang dapat dikembangkan salah satunya adalah game.

Game online merupakan alat permainan yang ada di era digital ini sebagai media hiburan. Kemunculan game online terjadi pada tahun 1960. Pada saat itu game online hanya dapat digunakan untuk 2 orang pemain saja dan di tempat yang sama. Kemudian pada tahun 1970 lahirlah jaringan komputer dengan basis paket yang tidak hanya sebatas jaringan area lokal yang mencakukp wilayah kecil namun telah mencakup area luas seperti antar negara atau antar benua. Dengan itu pemain bisa memainkan game online dengan pemain lebih banyak dan tempat lebih luas. Dalam sejarah game online di mulai sejak 1969 (Surbakti, 2017). Sejak awal, kemunculan game online berkembang dengan pesat dan menjadi sangat beraneka ragam jenisnya. Pada abad 21 kini, game online sudah menjadi bagian dalam kehidupan manusia. Semua kalangan dapat dengan mudah mengakses dan memainkan game dimana pun berada. Dengan kehadiran dan maraknya game online membuat peserta didik lebih menyukai bermain game dibadingkan dengan belajar. Pengaruh yang diberikan game online terhadap perseta didik sangat cepat dimana peserta didik sedang berada pada masa bermainnya. Peserta didik pada abad ini sulit dijauhkan dari bermain game (Syahran, 2015). Anak-anak sering lupa waktu ketika sudah asyik bermain game karena, merasa bahwa bermain game adalah hal yang sangat mengasyikkan. Hal tersebut membuat orang tua dan pendidik untuk ikut mengawasi penggunaan game yang berlebihan pada peserta didik. Salah satu tindakan yang bisa dilakukan yaitu dengan mengalihkan game online pada game dengan konten edukasi. Dengan game yang berisi edukasi, bisa dilakukan bermain dengan belajar.

Namun tidak semua game online berdampak negatif, tetapi ada juga game online yang berdampak positif bagi peserta didik. Banyak penelitian telah dilakukan mengenai penggunaan game sebagai media pembelajaran. Hasil penelitian menunjukkan bahwa suatu game dapat menjadi pilihan media pembelajaran interaktif (SujalwodanSukirman, 2017). Dengan membubuhkan materi pembelajaran dan peserta didik dapat menjadi pemain game dapat berlangsung kegiatan belajar bermain sekaligus belajar.

Belajar sambil bermain sering mendapat perhatian serius bagi para pendidik karena dapat memberi kontribusi positif dalam menyegarkan suasana belajar. Namun sering tidak diterima dikalangan tertentu karena dipandang dapat menyebabkan permainan yang lebih meninjil daripada belajarnya. Padahal permainan dimaksudkan untuk menciptakan suasana belajar yang dinamis, menarik perhatian, dan mendorong antusiasme belajar yang menyenangkan. Permainan dalam pembelajaran sering disebut belajar berbasis game atau permainan pendidikan. Istilah ini digunakan untuk membedakan permainan yang berkaitan dengan olahraga dengan permainan yang dirancang khusus untuk tujuan pembelajaran. Dengan demikian permainan pendidikan adalah strategi pembelajaran yang mengintregasikan pemain untuk mengembangkan sikap dan keterampilan dalam situasi yang menyenangkan (Yamin, 2018).

Penggunaan media game dalam pembelajaran matematika dapat meningkatkan motivasi belajar dan memberikan kesempatan kepada peserta didik dalam berlatih soal-soal matematika (Setyadi, 2017). Dewasa ini pemahaman tentang matematika peserta didik masih bersifat hafalan dan peserta didik masih kebingungan dalam membentuk konsep yang berupa simbol untuk menyelesaikan 
masalah dalam pecahan. Hal tersebut menimbulkan kesulitan peserta didik dalam menyelesaikan soal pemecahan masalah tentang pecahan. Berbagai faktor yang memengaruhi hasil belajar peserta didik, di antaranya dari faktor diri peserta didik, pendidik, metode pembelajaran dan lingkungan belajar yang semuanya saling terkait.

Dalam rangka untuk mencapai tujuan pembelajaran tersebut, guru dapat membuat media pembelajaran sebagai alat untuk menyampaikan materi pembelajaran. Media adalah komponen pembelajaran yang tidak dapat dipisahkan dengan proses belajar mengajar untuk mencapai tujuan pembelajaran di sekolah (Arsyad, 2013). Media pembelajaran digunakan untuk menyampaikan materi pembelajaran dengan harapan dapat merangsang perhatian dan minat peserta didik dalam belajar. Dengan bantuan media pembelajaran, maka proses pembelajaran akan lebih menarik, konkrit, dan mudah dipahami oleh peserta didik. Dengan adanya media pembelajaran guru juga dapat meminimalisir metode ceramah dalam proses pembelajaran. Seiring dengan perkembangan zaman banyak bermunculan media pembelajaran yang dikembangkan dengan teknologi seperti web edukasi, film dan game.

Pembelajaran Matematika adalah usaha untuk memotivasi dan memfasilitasi peserta didik dalam belajar Matematika. Peserta didik tingkat sekolah dasar masih dalam proses perkembangan tingkat berpikirnta. Pada tingkat sekolah dasar pembelajaran matematika merupakan suatu hasil pengujian yang menarik karena terdapat perbedaan karakteristik pada hakikat matematika dengan hakikat peserta didik. Oleh karena itu dibutuhkan penghubung untuk menetralisir perbedaan tersebut. Tujuan dalam proses pembelajaran matematika adalah agar peserta didik cerdas, terampil dan mampu memahami pengetahuan tentang matematika. Upaya yang dilakukan agar hal tersebut tercapai adalah melalui proses pemberian pengalaman belajar kepada peserta didik dengan kegiatan belajaran yang terencana. Keberhasilan pembelajaran matematika dipengaruhi oleh faktor dalam sistem proses pembelajaran. Salah satu faktor tersebut adalah metode pembelajaran. Hal tersebut dapat menentukan keberhasilan dalam proses pembelajaran dan tercapainya tujuan pembelajaran (Amir, 2014).

Penjelasan masalah tersebut, diperlukan sebuah media pembelajaran untuk membantu peserta didik dalam pemahaman matematika yang bermakna dan kontekstual. Dengan menggunakan media pembelajaran yang menyenangkan dan menarik, peserta didik akan antusias dengan pembelajaran sehingga peserta didik akan mudah menangkap materi yang disampaikan oleh guru.

Dengan penggunaan media pembelajaran yang tepat, peserta didik akan mendapatkan hasil belajar yang baik. Hasil belajar adalah sejumlah pengalaman yang diperoleh peserta didik yang mencakup kognitif, afektif, dan psikomotor. Belajar tidak hanya penguasaan konsep teori materi mata pelajaran saja, tapi juga penugasan kebiasaan, presepsi, kesenangan, minat bakat, penyesuaian sosial, macam-macam keterampilan, cita-cita, keinginan dan harapan. Belajar merupakan proses yang kompleks dan terjadinya perubahan perilaku pada saat proses belajar diamati pada perubahan perilaku peserta didik setelah dilakukan penilaian.

Berdasarkan uraian di atas peneliti berinisiatif untuk membuat sebuah media pembelajaran game PEKA (Pecahan Matematika) yang dapat digunakan untuk menunjang pembelajaran dan mengatasi keterbatasan media interaktif untuk muatan pelajaran matematika materi pecahan sehingga peneliti tertarik untuk melakukan penelitian dengan judul "Pengembangan Media Pembelajaran Game PEKA Untuk Meningkatkan Hasil Belajar Kognitif Pada Materi Pecahan". Tujuan dari penelitian ini 
adalah untuk membuat media game untuk memudahkan penyampaian materi pecahan dan memudahkan pemahaman peserta didik tentang materi pecahan. Keunggulan dari media pembelajaran game adalah peserta didik dapat belajar matematika dengan asyik dan tidak membosankan. Game tersebut tidak hanya dapat dimainkan disekolah namun juga dapat dimainkan dirumah, sehingga memudahkan peserta didik untuk dapat belajar dirumah.

\section{METODE PENELITIAN}

Penelitian ini merupakan jenis penelitian Research and Development (R\&D) atau penelitian dan pengembangan. Dalam penelitian dan pengembangan ini penulis menggunakan model yang dikembangkan oleh Borg \& Gall pada tahun 1983, namun pada penelitian ini hanya dilakukan sampai pada langkah uji validasi oleh ahli materi dan ahli media. Langkah-langkah penelitian meliputi: 1)Penelitian dan pengembangan informasi awal, 2)Perencanaan, 3) Pengembangan draf produk awal, 4)Uji coba awal, dan 5)Revisi produk. Berikut adalah grafik langkah-langkah penelitian dan pengembangan media game PEKA.

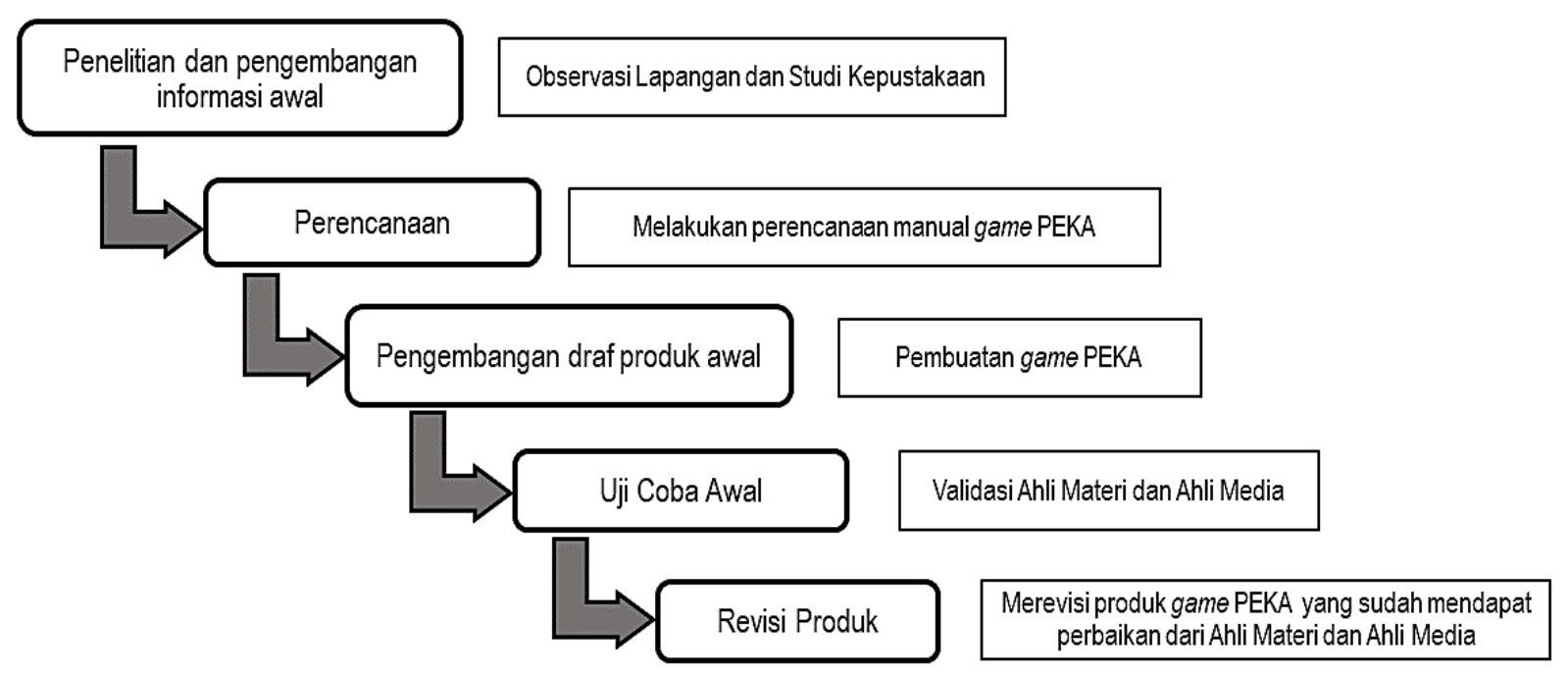

Gambar 1. Grafik langkah-langkah penelitian dan pengembangan

Dalam uji validasi ahli Terdapat 3 ahli materi dan 3 ahli media. Kisi-kisi instrumen validasi ahli materi dan ahli media yang digunakan dalam penelitian dan pengembangan media game PEKA adalah sebagai berikut.

Tabel 1. Kisi-kisi Uji Pakar Materi

\begin{tabular}{|l|l|}
\hline No. & \multicolumn{1}{c|}{ Indikator } \\
\hline 1. & Kesesuaian media game PEKA dengan kurikulum sekolah dasar \\
\hline 2. & Kesesuaian media game PEKA dengan kompetensi dasar matematika \\
\hline 3. & Kesesuaian dengan tingkat kemampuan peserta didik dengan materi operasi hitung pecahan \\
\hline 4. & Kelengkapan materi operasi hitung pecahan pada media game PEKA \\
\hline 5. & Kejelasan materi operasi hitung pecahan pada media game PEKA \\
\hline 6. & Keruntutan penyajian soal pada media game PEKA \\
\hline 7. & Kesesuaian soal pada game PEKA dengan materi operasi hitung pecahan kelas V SD \\
\hline 8. & Kebermanfaatan media game PEKA untuk meningkatkan hasil belajar kognitif \\
\hline 9. & Kejelasan bahasa yang digunakan dalam media game PEKA \\
\hline
\end{tabular}


Tabel 2. Kisi-Kisi Uji Ahli Media

\begin{tabular}{|l|l|}
\hline No. & \multicolumn{1}{|c|}{ Indikator } \\
\hline 1. & $\begin{array}{l}\text { Kesesuaian media game PEKA terhadap konten pembelajaran matematika operasi hitung pecahan kelas } \mathrm{V} \\
\text { SD }\end{array}$ \\
\hline 2. & Kesesuaian pemilihan tampilan background pada media game PEKA \\
\hline 3. & Kesesuaian penggunaan gambar pada media game PEKA \\
\hline 4. & Ketepatan bentuk teks dan gambar pada media game PEKA \\
\hline 5. & Kualitas sajian tampilan media game PEKA \\
\hline 6. & $\begin{array}{l}\text { Kesesuaian media game PEKA dengan materi pembelajaran matematika tentang operasi hitung pecahan } \\
\text { kelas V SD }\end{array}$ \\
\hline 7. & Pemanfaatan media game PEKA untuk mempermudah dalam pembelajaran matematika kelas V SD \\
\hline 8. & Pemanfaatan media game PEKA untuk meningkatkan hasil belajar kognitif peserta didik kelas V SD \\
\hline 9. & Kejelasan bahasa yang digunakan pada media game PEKA \\
\hline 10 & Kesesuaian dengan tingkat perkembangan peserta didik kelas V SD \\
\hline 11. & Kemudahan penggunaan media game PEKA \\
\hline
\end{tabular}

Analisis data uji validasi ahli materi dan media menggunakan teknik deskriptif kualitatif dan presentase untuk menggambarkan tingkat validitas. Cara yang dapat ditempuh yaitu dengan melihat skor pengukuran yang diperoleh dari ahli materi dan ahli media untuk kemudian dijumlah menggunakan rumus:

$$
\mathrm{AP}=\frac{\text { Skor Aktual }}{\text { Skor Ideal }} \times 100 \%
$$

Keterangan:

AP

Skor Aktual : : Skor yang diberikan oleh validator atau ahli

Skor Ideal : : Skor maksimal hasil kali jumlah item dengan skor maksimal dari masing-masing item berikut.

Angka presentasi yang diperoleh selanjutnya dikelompokkan kedalam kriteria penilaian tabel

Tabel 3. Kriteria Penilaian Uji Validasi

\begin{tabular}{|c|c|}
\hline Skor & Kriteria \\
\hline $80-100 \%$ & Sangat tinggi \\
\hline $61-80 \%$ & Tinggi \\
\hline $41-60 \%$ & Cukup \\
\hline $21-40 \%$ & Rendah \\
\hline $1-20 \%$ & Sangat rendah \\
\hline
\end{tabular}

\section{HASIL DAN PEMBAHASAN}

Pengukuran kebutuhan diperoleh dari hasil observasi yang telah dilakukan di SDN Salatiga 05. Didapatkan hasil bahwa pembelajaran matematika pada materi pecahan kelas $\mathrm{V}$ hanya menggunakan media buku dan LKS saja, sehingga peserta didik kurang antusias dalam mengikuti proses pembelajaran. Berdasarkan kondisi tersebut, maka diperlukan pengembangan media untuk meningkatkan antusias peserta didik dalam proses pembelajaran matematika pada materi pecahan. Media yang akan dikembangkan adalah media game berbasis web yang berisi latihan soal operasi hitung pecahan. Penelitian pengembangan dengan judul "Pengembangan Media Pembelajaran Game PEKA untuk Meningkatkan Hasil Belajar Kognitif Peserta Didik pada Materi Pecahan" adalah untuk mempermudah peserta didik dalam mengerjakan operasi hitung pecahan matematika sehingga dapat meningkatkan hasil belajar kognitif. 
Software yang digunakan dalam pembuatan game PEKA adalah Construct 2. Komponen yang terdapat dalam media game PEKA adalah 1) Halaman pembuka, terdiri dari 3 halaman. Halaman yang pertama terdapat nama game PEKA berbentuk logo, halaman kedua dan ketiga berisi tujuan dari di buatnya game PEKA. 2) Halaman menu, terdapat pilihan-pilihan menu yaitu, mulai, cara main, dan keluar. 3) Menu cara main, terdapat 2 halaman pada menu cara main, yaitu halaman cara main yang berisi langkah-langkah dalam memainkan game PEKA dan halaman informasi yang berisi informasi tentang pembuat dan tujuan dari pembuatan game PEKA. 4) Pilihan operasi hitung pecahan, dalam komponen pilihan operasi hitung pecahan terdapat pilihan penjumlahan, pengurangan, pembagian, pembagian, dan menu kembali. 5) Soal-soal operasi hitung pecahan, dalam komponen ini berisi soalsoal operasi hitung yang harus diselesaikan hingga mendapatkan hasil akhir dari pengerjaan soal-soal.

Setelah draft produk game PEKA dikembangkan, selanjutnya adalah melakukan uji validitas media. Validasi ahli adalah tahapan memvalidasi produk media game PEKA yang dilakukan oleh ahli materi dan ahli media. Validasi ahli dilakukan dengan tujuan agar media game PEKA mendapat kritik dan saran dari pakar dibidang tersebut sehingga media game PEKA layak untuk digunakan dalam penelitian. Berikut adalah daftar nama ahli materi dan ahli media.

Tabel 4. Hasil Validasi Ahli Materi

\begin{tabular}{|l|cc|c|}
\hline \multicolumn{1}{|c|}{ Ahli Materi } & $\begin{array}{c}\text { Skor } \\
\text { Perolehan }\end{array}$ & $\begin{array}{c}\text { Skor } \\
\text { Maksimal }\end{array}$ & $\begin{array}{c}\text { Kriteria } \\
\text { Penilaian }\end{array}$ \\
\hline Erlina Prihatnani, S.Si., M.Pd. & $91 \%$ & $100 \%$ & Sangat baik \\
\hline Indri Anugraheni, S. Pd., M. Pd. & $82 \%$ & $100 \%$ & Sangat baik \\
\hline Yohana Setiawan, M. Pd. & $78 \%$ & $100 \%$ & Baik \\
\hline Rata-rata keseluruhan & $84 \%$ & $100 \%$ & Sangat Baik \\
\hline
\end{tabular}

Penilaian yang diberikan oleh validator materi memperoleh rata-rata $84 \%$ yang menunjukkan kriteria penilaian sangat baik. Validator materi menilai produk media game PEKA dari 9 indikator, yaitu kesesuaian dengan kurikulum SD, kesesuaian dengan kompetensi dasar matematika kelas V SD, kesesuaian dengan tingkat kemampuan peserta didik kelas $\mathrm{V} S \mathrm{D}$, kelengkapan materi, kejelasan materi, keruntutan penyajian soal, kesesuaian soal dengan materi, kebermanfaatan untuk meningkatkan hasil belajar kegnitif, dan kejelasan bahasa. Media game PEKA dinilai sudah sesuai dengan kurikulum SD yang ditunjukkan dengan rata-rata skor 4,7. Media game PEKA sesuai dengan kempetensi dasar matematika kelas $V$ yang ditunjukkan dengan rata-rata skor 4. Kesesuaian soal pada game PEKA sesuai dengan tingkat kemampuan kognitif peserta didik kelas V SD dalam materi operasi hitung pecahan yang ditunjukkan dengan rata-rata skor 4,3. Kelengkapan materi operasi hitung dalam game PEKA dinilai sudah lengkap ditunjukan dengan rata-rata skor 4. Keruntutan penyajian soal sudah dinilai runtut dengan rata-rata skor 4 . Kesesuaian soal pada game PEKA dengan operasi hitung pecahan kelas $V$ SD sudah dinilai sesuai dengan rata-rata skor 4,7. Kebermanfaatan media game PEKA untuk meningkatkan hasil belajar kognitif sudah dinilai bermanfaat dengan rata-rata skor 4,3. Kejelasan bahasa yang digunakan dalam media game PEKA mudah dipahami dengan rata-rata skor 4,3. Penggunaan media game PEKA dalam pembelajaran adalah bertujuan untuk membantu peserta didik dalam memahami materi operasi hitung pecahan. Game PEKA berisi soal-soal operasi hitung pecahan dari pecahan biasa dengan penyebut yang sama sampai pecahan campuran. Dengan begitu peserta didik dapat berlatih soal operasi hitung pecahan dengan runtut. 
Tabel 5. Hasil Validasi Ahli Media

\begin{tabular}{|l|c|c|c|}
\multicolumn{1}{|c}{ Pakar Media } & $\begin{array}{c}\text { Skor } \\
\text { Perolehan }\end{array}$ & $\begin{array}{c}\text { Skor } \\
\text { Maksimal }\end{array}$ & $\begin{array}{c}\text { Kriteria } \\
\text { Penilaian }\end{array}$ \\
\hline T. Arie Setiawan, S.T, M.Cs. & $100 \%$ & $100 \%$ & Sangat Baik \\
\hline Mila Chrismawati Paseleng, S. Si., M. Pd. & $80 \%$ & $100 \%$ & Sangat Baik \\
\hline Adriyanto Juliastomo Gundo, S. Si., M. Pd. & $95 \%$ & $100 \%$ & Sangat Baik \\
\hline Rata-rata keseluruhan & $92 \%$ & $100 \%$ & Sangat Baik \\
\hline
\end{tabular}

Penilaian yang diberikan oleh validator media memperoleh rata-rata $92 \%$ yang menunjukkan kriteria penilaian sangat baik. Validator media menilai produk media game PEKA dari 11 indikator, yaitu kesesuaian media game PEKA terhadap konten pembelajaran matematika operasi hitung pecahan kelas V, kesesuaian background pada game, kesesuaian gambar pada game, ketepatan bentuk teks dan gambar pada game, kualitas sajian tampilan game, kesesuaian game dengan materi operasi hitung pecahan kelas $\mathrm{V}$, pemanfaatan game untuk mempermudah dalam pembelajaran matematika kelas $\mathrm{V}$, pemanfaatan game untuk meningkatkan hasil belajar kognitif peserta didik kelas $\mathrm{V}$, kejelasan bahasa, kesesuaian dengan tingkat perkembangan peserta didik kelas $\mathrm{V}$, dan kemudahan penggunaan game. Media game PEKA sudah dinilai sangat sesuai terhadap konten pembelajaran matematika operasi hitung pecahan kelas V SD ditunjukkan dengan skor rata-rata 5 . Ketepatan bentuk teks dan gambar mendapat rata-rata skor 3,7 dengan predikat sedang. Ketepatan game dengan materi matematika tentang operasi hitung pecahan kelas $\mathrm{V}$ sudah tepat ditunjukkan dengan rata-rata skor yaitu 5. Kesesuaian game dengan tingkat perkembangan peserta didik kelas V SD dinilia sudah sesuai, ditunjunjukkan dengan rata-rata skor 5 . Kemudahan penggunaan game dinilai sudah sesuai ditunjukkan dengan rata-rata skor 5. Media game PEKA sesuai dengan perkembangan peserta didik SD dan mudah digunakan. Media pembelajaran ini disusun menjadi media pembelajaran yang menarik minat belajar peserta didik, sehingga peserta didik akan lebih termotivasi dalam belajar operasi hitung pecahan.

Dari pakar materi didapatkan skor rata-rata keseluruhan yaitu $84 \%$ dengan kriteria penilaian sangat baik. Sedangkan pakar media didapatkan skor rata-rata keseluruhan yaitu $92 \%$ dengan kriteria penilaian sangat baik. Berdasarkan nilai yang didapat media game PEKA layak digunakan setelah dilakukan perbaikan dengan sesuai saran dari pakar materi dan media.

Pembahasan ini dikuatkan dengan penelitian yang sudah dilakukan oleh oleh Rosita Dewi pada tahun 2017 bahwa media pembelajaran game dapat memberikan peningkatan pada hasil belajar peserta didik yang menggunakan dengan yang tidak menggunakan media pembelajaran game (Rosita Dewi, 2017). Media pembelajaran berupa game dapat menumbuhkan motivasi belajar bagi peserta didik. Dalam bermain game selain mendapatkan hiburan peserta didik juga dapat pengetahuan dan pembelajaran.

Pada tahap revisi produk dilakukan perbaikan media game PEKA sesuai dengan saran dari pakar materi dan pakar media. Skor yang didapat pada validasi pakar materi dan media termasuk dalam kategori sangat baik, namun terdapat saran untuk perbaikan media game PEKA.

\section{SIMPULAN}

Media pembelajaran game PEKA dibuat dengan menggunakan aplikasi Construct 2. Game PEKA menyajikan materi operasi hitung pecahan yaitu penjumlahan, pengurangan, perkalian, dan pembagian. Pemain dari game PEKA dapat mengerjakan soal-soal operasi hitung pecahan dari level 120 dan setelah mengerjakan pemain bisa melihat skor yang didapatkan dari pengerjaan soal tersebut. 
Saat mengerjakan, pemain juga berpacu dengan waktu dengan 2 menit untuk setiap soal. Dengan menggunakan media ini ditujukan agar peserta didik dapat belajar dan bermain serta dapat meningkatkan kemapuan kognitif.

Media game PEKA yang telah dikembangkan telah melalui uji pakar. Berdasarkan hasil uji pakar oleh pakar materi dan pakar media, memperoleh hasil media game PEKA mendapat skor dengan kriteria sangat baik. Rata-rata yang diperoleh dari pakar materi adalah $84 \%$ dengan kriteria penilaian sangat baik dan rata-rata yang diperoleh dari pakar media adalah $92 \%$ dengan kriteria penilaian sangat baik.

\section{DAFTAR RUJUKAN}

Amir, A. (2014). Pembelajaran Matematika SD dengan Menggunakan Media Manipulatif. Forum Paedagogik, VI(01), 72-89.

Arsyad, A. (2013). Media Pembelajaran. Rajawali Pers.

Rosita Dewi, F. (2017). Pengembangan Media Pembelajaran Berbasis Game Edukasi Bergenre SideScroliing Platformer. It-Edu, 2(01), 92-96.

Setyadi, D. (2017). Pengembangan Mobile Learning Berbasis Android Sebagai Sarana Berlatih Mengerjakan Soal Matematika. Satya Widya, 33(2), 87-92.

https://doi.org/10.24246/j.sw.2017.v33.i2.p87-92

SujalwodanSukirman. (2017). Pengembangan Game Berbasis Komputer Sebagai Media. Jurnal Managemen Pendidikan, 122(2), 239-247.

Surbakti, K. (2017). Pengaruh Game Online Terhadap Remaja. Jurnal Curere, 01(01), 28-38.

Syahran, R. (2015). Perilaku Yang Ditimbulkan Dari Kecanduan Game Online Pada Siswa SMP Negeri 1 Palu. Jurnal Psikologi Pendidikan Dan Konseling: Jurnal Kajian Psikologi Pendidikan Dan Bimbingan Konseling, 1(1), 84-92.

Yamin, M. (2018). Media dan Teknologi Pembelajaran. Prenademedia Group. 